\title{
A 40,000 year wood charcoal record from Carpenter's Gap 1: New insights into palaeovegetation change and indigenous foraging strategies in the Kimberley, Western Australia
}

\section{Susan Frawley}

Archaeology and Natural History, College of Asia and the Pacific, Australian National University, Canberra, Australia

\section{Sue $0^{\prime}$ Connor}

Archaeology and Natural History, College of Asia and the Pacific, Australian National University, Canberra, Australia

sue.oconnor@anu.edu.au

\section{Introduction}

This paper presents the results from analysis of wood charcoal from Carpenter's Gap 1, a rock shelter with a human-occupation record spanning more than 40,000 years. The phytolith and macrobotanical remains from this site have been previously studied. They provided proxy records of vegetation change over time but each class of palaeobotanical material has distinct taphonomic biases that affect the likelihood that it will be incorporated in the archaeological deposit, and if it is, how well it preserves. The wood charcoal record provides a new line of evidence and helps build a more holistic profile of palaeovegetation local to the site and human foraging strategies over the 40,000 year span of its occupation.

\section{Background}

Carpenter's Gap 1 is a large rock shelter located in the Oscar Napier Range, between $14^{\circ} \mathrm{S}$ and $19^{\circ} \mathrm{S}$ latitude and $123^{\circ} \mathrm{E}$ to $129^{\circ} \mathrm{E}$ longitude within Windjana Gorge National Park (Figure 1). The shelter is on the north-facing side of the range, approximately $4 \mathrm{~km}$ from Windjana Gorge and the Lennard River, c. $25 \mathrm{~m}$ above the surrounding plain. Carpenter's 
Gap 1 is spacious, with a floor area of more than $50 \mathrm{~m}^{2}$, and contains a considerable amount of painted rock art and engravings (O’Connor 1995) (Figures 2 and 3).

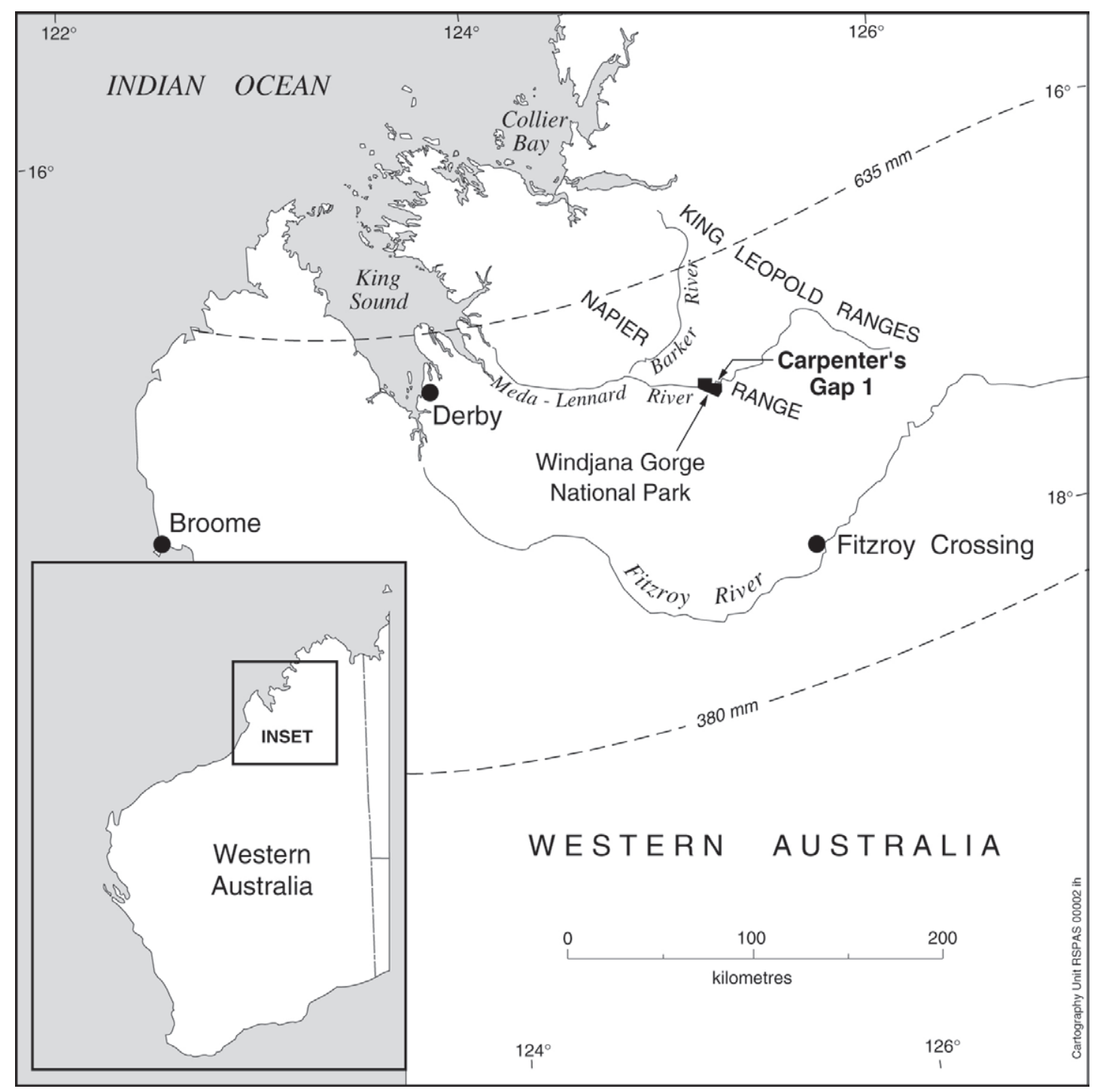

Figure 1. Map showing location of Carpenter's Gap 1

The shelter was excavated by O'Connor over two field seasons between 1993 and 1994 (McConnell and O'Connor 1999; see Figure 3). Its significance lies in its long occupation record and the fact that it preserves a wealth of organic materials, including charcoal and macrobotanic remains, even in the earliest occupation levels. Preliminary reports on the archaeological results have been published elsewhere (O'Connor 1995; McConnell and O'Connor 1999). Radiocarbon dating of the lower levels of the excavated deposit produced a maximum age estimate of 42,800 \pm 1850 BP OZD161 (McConnell and O'Connor 1999). Archaeological sequences with this level of preservation and chronological resolution are rare anywhere in Australia, and particularly so in northern Australia, where the monsoon tropical environment usually rapidly destroys organic materials. Well-resolved late PleistoceneHolocene terrestrial records for palaeovegetation change have also proved elusive, as lakes and other natural deposits preserving continuous pollen records are few in northwest Australia (Hiscock and Wallis 2005).

Carpenter's Gap 1 is unique, as it preserves plant phytoliths, wood charcoal, pollen and macrobotanic remains, as well as organic and non-organic residues of human behaviour and thus provides a window into palaeoenvironmental change and the human behavioural responses 
Figure 2. Carpenter's Gap 1, view facing west. Excavation area is behind the large boulder in the shadowed area
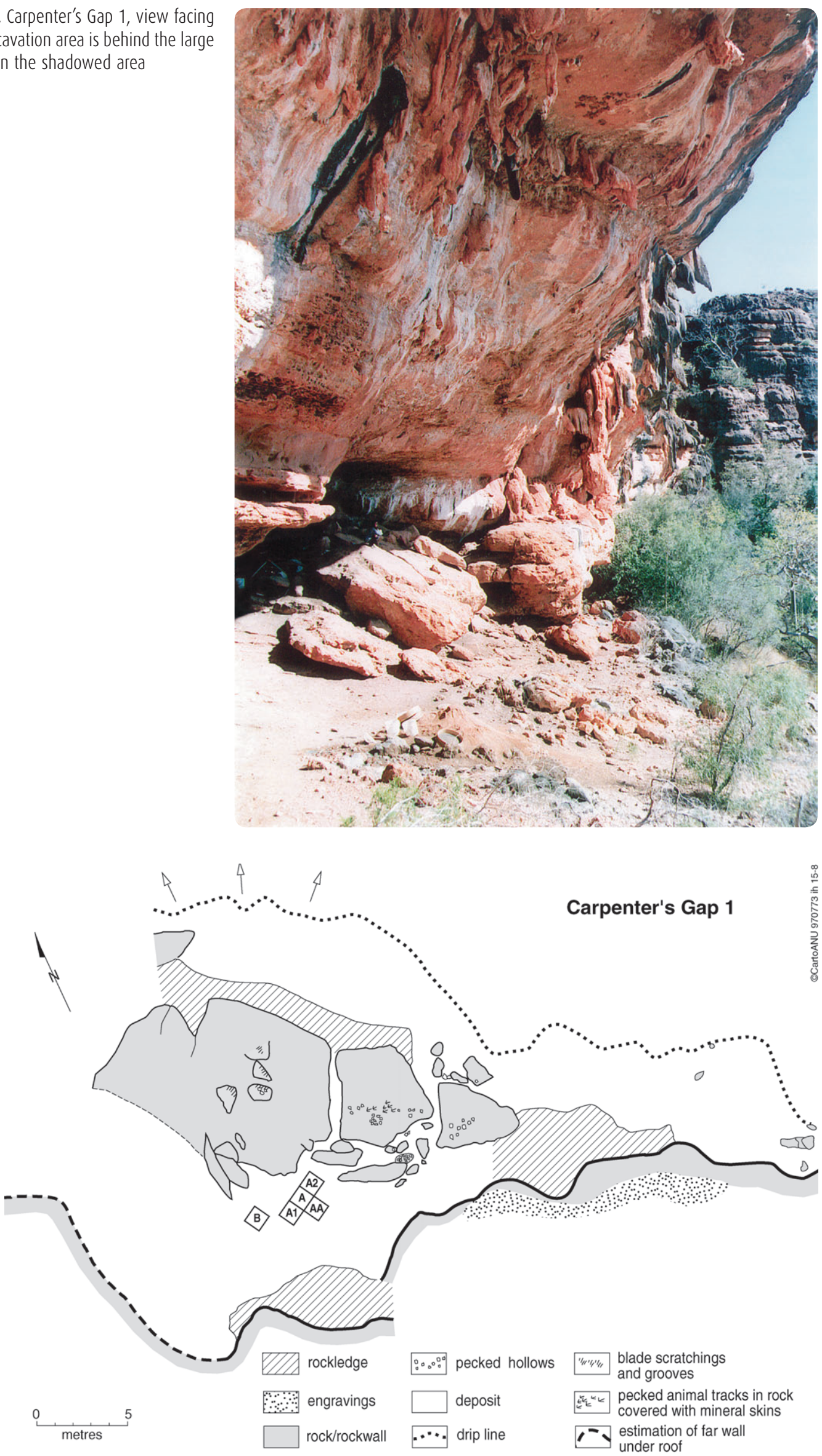

Figure 3. Plan of Carpenter's Gap 1 showing excavation areas 
to it, before, during and after the Last Glacial Maximum (McConnell and O'Connor 1997; Wallis 2000, 2001).

\section{Contemporary vegetation in the site surrounds}

Four botanical districts are described for the Northern Botanical Province (Kimberley) by Beard (1979:14-17). The Napier Range lies predominantly within the Dampier District, but is in close proximity to the Fitzgerald District. Beard (1979:96) described the regional vegetation on the limestone outcrops as sparse, consisting primarily of the spinifex Triodia wiseana, along with some other grasses. Boabs, Adansonia gregorii, are scattered on the slopes and plains, along with small trees such as Sterculia viscidula, Celtis philippensis, Cochlospermum fraseri, Ficus opposita, Terminalia spp. and Wrightia sp. The foot slopes of the limestone ranges have a tree steppe of Eucalyptus dichromophloia and Triodia wiseana (Beard 1979:96). McConnell (McConnell and O'Connor 1997:20) and Wallis (2000:100102) carried out field trips to the Napier Range with the specific purpose of collecting and identifying the range of taxa occurring in vicinity of Carpenter's Gap 1, and extended the known taxa for this area. As will be discussed below, Frawley (2010) also carried out a collecting trip to acquire and identify samples to form the basis of the modern wood comparative collection.

\section{Previous palaeobotanical studies at Carpenter's Gap 1}

McConnell's (1997) study of the macrobotanic remains at Carpenter's Gap 1 identified significant changes in the species present through time. Almost 2500 plant fragments were analysed, the majority of which are seeds. Other types of material recovered include seed casings, bamboo fibre, tubers, uncharred wood shavings and wood fragments, grass stems, leaves, bark and fibres. McConnell subdivided the assemblage into four time phases which she used to infer a vegetation history for the site surrounds. She downplayed the effects of variable decay, based on a series of taphonomic studies she undertook in the field, arguing instead that the assemblage is a good reflection of the palaeovegetation over time (McConnell and O'Connor 1997:25).

There was little macrobotanic material preserved in the lowest levels between 42,000 BP and 35,000 BP, but Plectrachne sp. (grass), Cyperaceae (sedges - aquatic perennial herbs) and occasional seeds of Terminalia spp. were recovered. The latter has an edible fruit with a large woody seed that preserves well, and is the most common food seed recovered at Carpenter's Gap 1 (McConnell and O'Connor 1997) and at other Kimberley shelters (e.g. O'Connor 1999:82). Terminalia seeds are well represented at Carpenter's Gap 1 in levels dated between 35,000 BP and 30,000 BP and are abundant in the Holocene levels, but are found in very low numbers in all levels dated between 15,000 BP and 22,000 BP. Plectrachne and Cyperaceae are found in the levels dated between 30,000 BP and 25,000 BP, along with a variety of fruit and vine species, such as Terminalia spp., Ampelocissus acetosa and Vitex glabrata. However, the fruiting tree species decrease after about 25,000 BP.

Recovered in abundance in levels corresponding with the LGM were Chenopodiaceae (saltbush and bluebush - including saltbush Atriplex spp.) and Cyperaceae. The presence of chenopods, grasses and spinifex indicates poor, saline or calcareous soils and dry conditions and would not be unexpected at this time. However, the abundance of the aquatic-associated plants is unexpected. Sedges are found only in moist locations and their closest occurrence to the site today is the edges of the permanently wet pools in the Lennard River, about $4 \mathrm{~km}$ to the northwest. The most recent phase of the site's history, the Holocene, again sees a large input of seeds of broad-leaf deciduous tree and vine fruits of common edible species such as are found around the site today. These include Ampelocissus acetosa, Terminalia spp., Vitex glabrata and Celtis 
philippensis. Fragments of the seed case of boabs, Adansonia gregorii, are also well represented in these levels. Significantly, the grasses and sedges prevalent in the Pleistocene layers disappear from the record in the Holocene (McConnell and O'Connor 1997:26).

On the basis of these changes, McConnell inferred major fluctuations in the regional environment. She argued the earliest phase, from 42,000 BP to 35,000 BP, can be characterised 'as a grassland of perennial tall tropical grasses and sedges growing around permanent streams and wetlands, with shifting dunes creating inroads in the wetlands' (McConnell and O'Connor 1997:29). The increase in seeds of deciduous fruit trees between 35,000 BP and 25,000 BP is interpreted by McConnell as indicating that vine thicket/rainforest may have been more extensive, and indicating 'an increase in moisture sufficient to maintain deciduous trees which have higher water requirements than grasses' (McConnell and O'Connor 1997:29). The increase in grasses and shrubs and decline in vine thicket species from 25,000 BP to 11,000 BP is argued to be firm evidence for an arid phase, but with sufficient stands of water to support the Cyperaceae sedges. McConnell and O'Connor (1997) make a strong case that the prevalence of grass seeds in the spits with dates of between 20,000 BP and 18,000 BP reflects their importance as an alternate food or drought food as conditions became more arid. There is a substantial ethnobotanical literature on the use of chenopods and grass seed in arid Australia that provides an empirical basis for this proposition (e.g. Crawford 1982; O'Connell et al. 1983; Goddard and Kalotas 1985; Latz 1995). While there are no ethnographic records for the use of grass seed as food or for seed grinding in this area of the Kimberley, it is possible that grasses were eaten only to expand the food base during more arid times (Gorecki et al. 1997:148). Portable grindstones were not found in the deposit, although grinding patches and pecked and ground hollows were recorded as part of the fabric of the shelter and may have been used for this purpose (O'Connor pers obs.).

McConnell and O'Connor (1997:29) proposed that the macrobotanic record indicates a generally drier environment in the Holocene than during the pre-LGM late Pleistocene. The reappearance of the vine thicket/rainforest taxa in the Holocene is seen as indicating an 'increase in available moisture, but with insufficient surface water to maintain the sedges and perennial grasses' (McConnell and O'Connor 1997:29).

In 2000, Wallis $(2000,2001)$ made a major study of the phytolith assemblage from Carpenter's Gap 1 for her PhD dissertation. In constructing a modern reference collection, Wallis (2000:151) found that many of the modern tree and shrub plant samples produced no, or limited, phytoliths and hence would not be expected to be represented in the Carpenter's Gap assemblage. However, as grasses are abundant phytolith producers, they are better represented in the assemblage. Like McConnell, she separated the site assemblage into four phases based on the available radiocarbon dates and used the palaeobotanical record to infer a vegetation history for the site. Her findings and interpretations, however, differ quite markedly from McConnell's.

Wallis's Phase 1, dated between c. 40,000 BP and 30,000 BP, was characterised by an assemblage dominated by grassland communities similar to those seen in the study area today, although she identified a wider range of taxa than McConnell. A low representation of phytoliths derived from spinifex and other arid grasses was interpreted as indicating that at this time these arid-tolerant species were spatially restricted to the rocky slopes of the range (Wallis 2001:112). Surprisingly, two distinct types of palm phytoliths were found in considerable abundance between 40,000 BP and 30,000 BP (Wallis 2001:113) and in minor quantities until just before the LGM, after which time they are absent from the record. Palms are dependent on permanent water. They do not occur in the Napier Range today, even in areas that retain freshwater pools throughout the dry season, such as the pools on the Lennard River at Windjana Gorge. Their nearest occurrence to Carpenter's 
Gap today is approximately $40 \mathrm{~km}$ to the north, on the margins of the King Leopold Range. Palms are very useful plants and recorded as an important food source for local indigenous people. The centre of the palm, known as the 'heart', was eaten and the fronds were used for basketry (Crawford 1982) so it is not surprising that they would be transported some distance to a habitation site. However, $40 \mathrm{~km}$ is well outside the limits of a daily foraging range. Therefore, while she recognised a human agency in the transport of palms to the site, Wallis (2001:113) argued that their previous geographic range must have extended southwards, suggesting wetter conditions than at present in the inland southwest Kimberley between 40,000 BP and 30,000 BP.

Vegetation change over time was also evident in the distribution of Ulmaceae phytoliths. As with the palms, two distinct forms differentiated by size were present. These were comparable with the modern leaf and seed phytoliths from Celtis philippensis and Trema tomentosa. Members of this family are associated with vine thicket as they have reasonably high water requirements. The Ulmaceae phytoliths occur in the 40,000 BP to 30,000 BP deposits, disappear during the LGM, and reappear in the Holocene-aged deposits (Wallis 2001:114). The fruits of these species are an important indigenous food (Crawford 1982) and it seems unlikely they would be neglected if they were locally available. Their complete absence in the LGM levels of the sequence is argued by Wallis (2001:114) to constitute good evidence of their disappearance from the local environment with increasing aridity, and their return in the late Holocene to signal the return to moister conditions.

While the overall phytolith record for the LGM could be interpreted as indicating increased aridity, Wallis identified some undeniable indicators of wet conditions, notably sedges, diatoms and sponge spicules. These appear at precisely the time when they would be least expected in the sequence, as climatic conditions deteriorate. Diatoms are associated with moist habitats such as streams, lakes and swamps, and freshwater sponges also require permanent bodies of standing water for their survival. Unlike McConnell, Wallis did not interpret these remains as a direct reflection of their availability in the immediate site environment, instead seeing human agency and variable preservation as playing a strong part in the formation of the palaeobotanical record. Sedge bulbs are an important late-dryseason food for Aboriginal people in the Kimberley (Crawford 1982) and the stems are also used to cover wooden and bailer-shell water carriers during transport to minimise spillage and evaporation (O'Connor pers obs.). Today, the closest source of standing freshwater in any quantity is the Lennard River about $4 \mathrm{~km}$ to the northwest. However, small quantities of freshwater (enough for the daily requirements of a small family group) can be obtained from seepage through the limestone at Carpenter's Gap 1 and at many points along the range (O'Connor pers obs.). Even at the height of the dry season it is not necessary to travel to the Lennard River to obtain a small quantity of freshwater. However, the drier conditions during the LGM may have led to the loss of local seepages and necessitated greater mobility to acquire water (Wallis 2001). People bringing water from the Lennard River may have covered their water containers with sedges, or brought back sedge stems with the bulbs. The diatoms and sponge spicules may also have been inadvertently collected and transported with the aquatic plants.

\section{The wood charcoal sequence at Carpenter's Gap 1}

Edgar (2001) undertook a pilot study of a small sample of the wood charcoal remains from Carpenter's Gap 1 for his honours dissertation. He examined 40 archaeological charcoal samples from Square A, of which 25 (62\%) were identifiable to at least family level (Edgar 2001:214). He identified four species, four genera and one family. These were Proteaceae including Grevillea sp. and Hakea arborescens, Terminalia spp. including T. arostrata, 
Eucalyptus spp. including E. miniata, Grewia breviflora and Ficus sp. He subdivided the sample into the same time periods as Wallis (2000), however his attempts to examine change through time were frustrated by the small sample size and limited range of taxa. The limited modern reference material at his disposal also constrained the number of positive identifications. The prime value of Edgar's study was that it showed the potential of wood charcoal for providing a further line of evidence on the palaeovegetation of the southern Kimberley (Edgar 2001:214).

The current study reports the results of the analysis of a larger quantity of excavated charcoal than analysed by Edgar, as well as the samples identified by Edgar, and thus provides a firmer basis for comparison of the wood charcoal with the macrobotanic and phytolith records.

\section{Creating the modern reference collection}

There were two sources for the modern reference materials used in this research. In 2006, Frawley undertook a field trip to the Napier Range to make a collection of modern wood from species growing in the surrounds of Carpenter's Gap 1, with which the archaeological material could be compared for identification. When collecting the samples, a point was made to obtain them from a range of representative environments in the vicinity of the rock shelter. Of note were the different moisture levels and inherent differences in the ecosystems between the open sandy plain below the shelter, the rocky talus slopes outside the shelter entrance, and moister environments such as the seasonal creek lines and within Windjana Gorge. Windjana Gorge is host to plants that rely on a constant water supply, whereas the other more arid talus slopes of the Napier Range were characterised by different plants that were generally more drought tolerant and suited these environments.

Tree species were sampled from Windjana Gorge National Park campground and surrounding areas, on the talus slope immediately in front of the entrance to Carpenter's Gap 1, from the plain below the shelter, from the banks of the river channel within Windjana Gorge, and from the sand dunes and plain to the south of the Napier Range. The reference collection comprises trees from three different ecosystems: the gorge/riverine environment, vine thicket and dry savannah. Samples were collected in accordance with guidelines outlined by Pearsall (1989), and where possible, branches were cut to include seed pods for more accurate identification. In some cases, only a single tree was available for collection.

Specimens were identified using reference books and with the assistance of the CALM Ranger at Windjana Gorge, Rod O'Donnell. The sample branches were preserved by enclosing the specimens in newspaper and placing them between layers of a cardboard press. Thirty-one samples were collected during the 2006 field trip. The branches were transported to Perth where they were identified, or the field identification was confirmed, by botanists at the WA Herbarium.

The identified tree specimens were brought back to the Australian National University (ANU) where the branches were processed to create the modern reference collection (Figures 4 and 5). A small section, approximately $4 \mathrm{~cm}$ in length, was cut from each branch, wrapped in aluminium foil and placed in a ceramic crucible. These were then placed in a muffle furnace and heated to $400^{\circ} \mathrm{C}$ for an hour. The resulting charcoal was then cut for SEM imaging and small sections were prepared for mounting on a stub. The mounted sample was cut along the transverse section across the diameter. This was then split at a $90^{\circ}$ angle to produce both a tangential and a radial face, and then mounted on stubs using carbon tape. This reduced the need for multiple samples, as the stage within the SEM could be rotated so that all three faces of the sample could be viewed without removal or remounting. Each stub was coated with a $20 \mathrm{~nm}$ coating of gold before viewing. Full information on species collected and all the SEM photographs can be found in Frawley (2010:Appendix 2). A selection of identified species from the comparative collection is presented in Figures 4 and 5. 


\section{Comparative Collection}
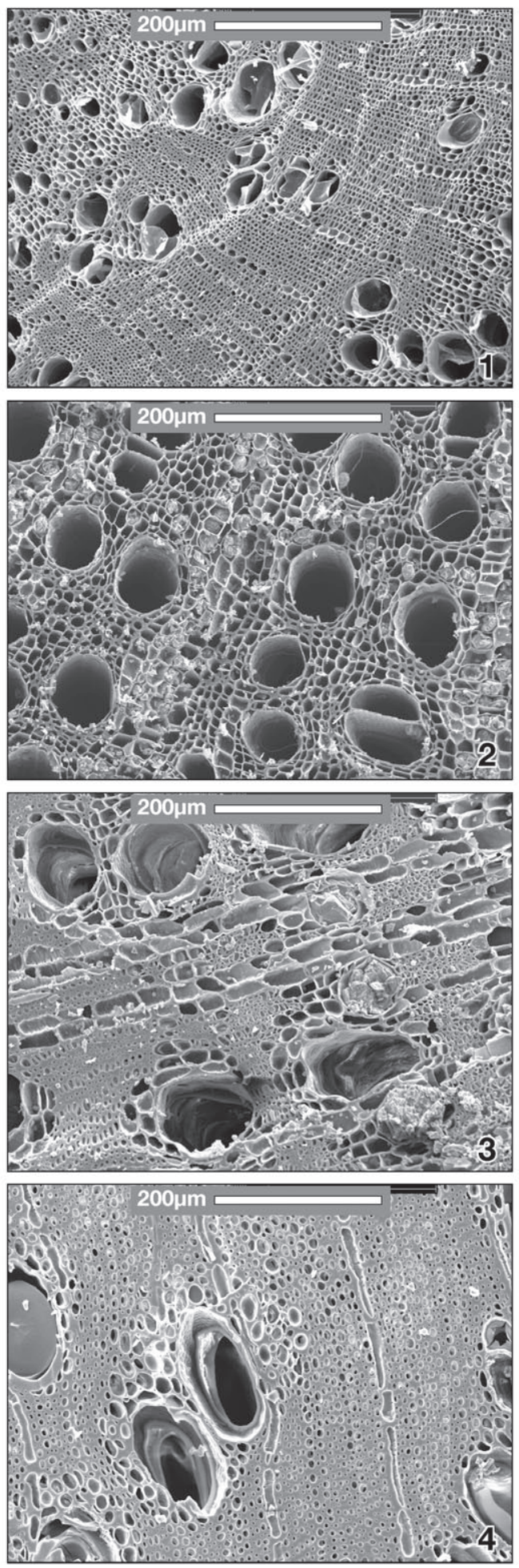

1. Cochlospermum fraser

2. Andansonia gregorii

3. Terminalia arostrata

4. Acacia platycarpa
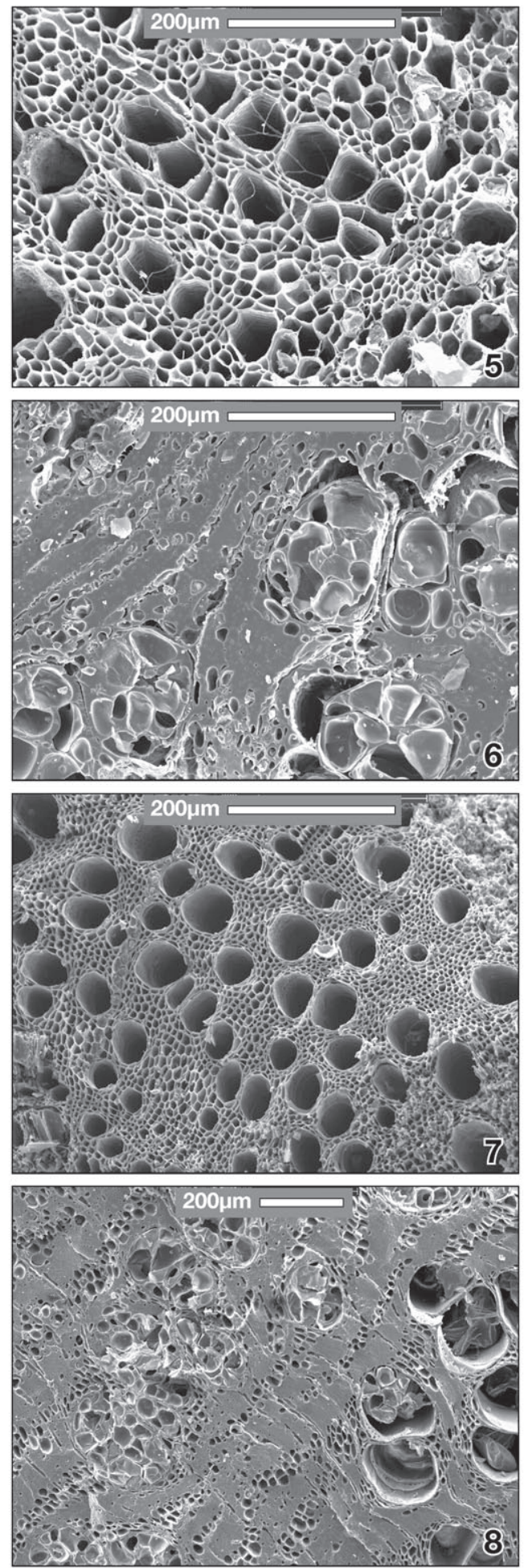

5. Ficus platypoda

6ucalyptus bleeseri

7. Eucalyptus camaldulensis

8. Eucalyptus ferruginea

Figure 4. Wood charcoal SEM images for species in the comparative collection 

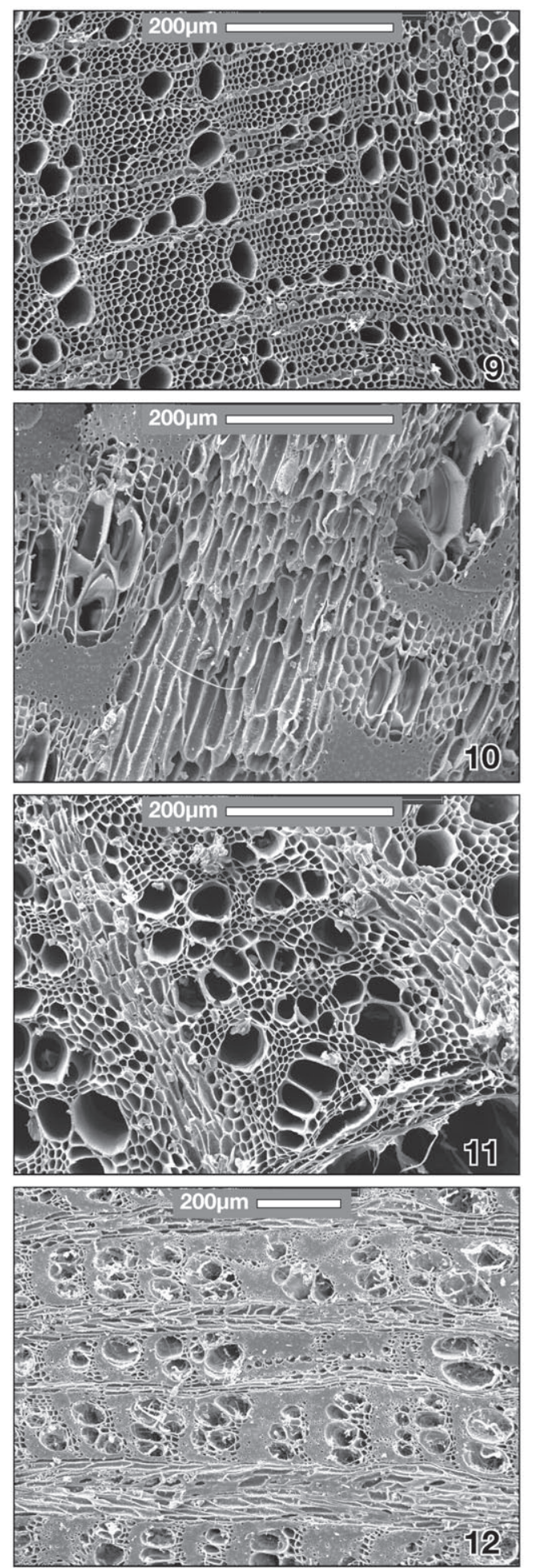

9. Melaluca leucadendra

10. Grevillea heliosperma

11. Grevillea pyramidalis

12. Hakea arborescens
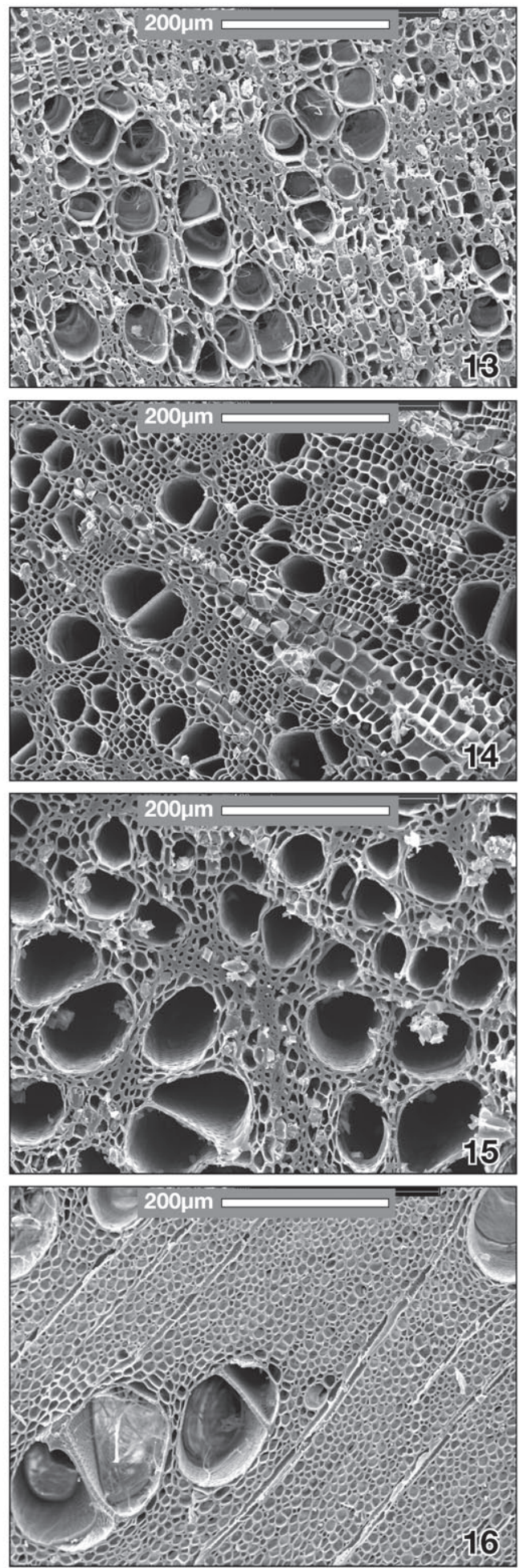

13. Pouteria seracia

14. Brachychiton diversifolius

15. Corymbia dampiere

16. Acacia holosericea

Figure 5. Wood charcoal SEM images for species in the comparative collection 
In addition to the samples collected by Frawley, 25 charcoal samples which had been prepared by Edgar (2001) were made available for this study. Combined, this provided a total of 56 samples of species from 22 families.

\section{Sampling the archaeological charcoal}

The site yielded a high volume of well-preserved charcoal but only a small sample of it could be processed and analysed for this study.

The charcoal samples selected for analysis were from excavation Square A2 as this excavation area had the greatest number of spits and contained the largest quantities of charcoal (Figure 6). The spits selected for analysis were those that had been dated by O'Connor (O'Connor unpub. data, Table 1). Four additional dates were obtained during this study and are highlighted in Table 1.

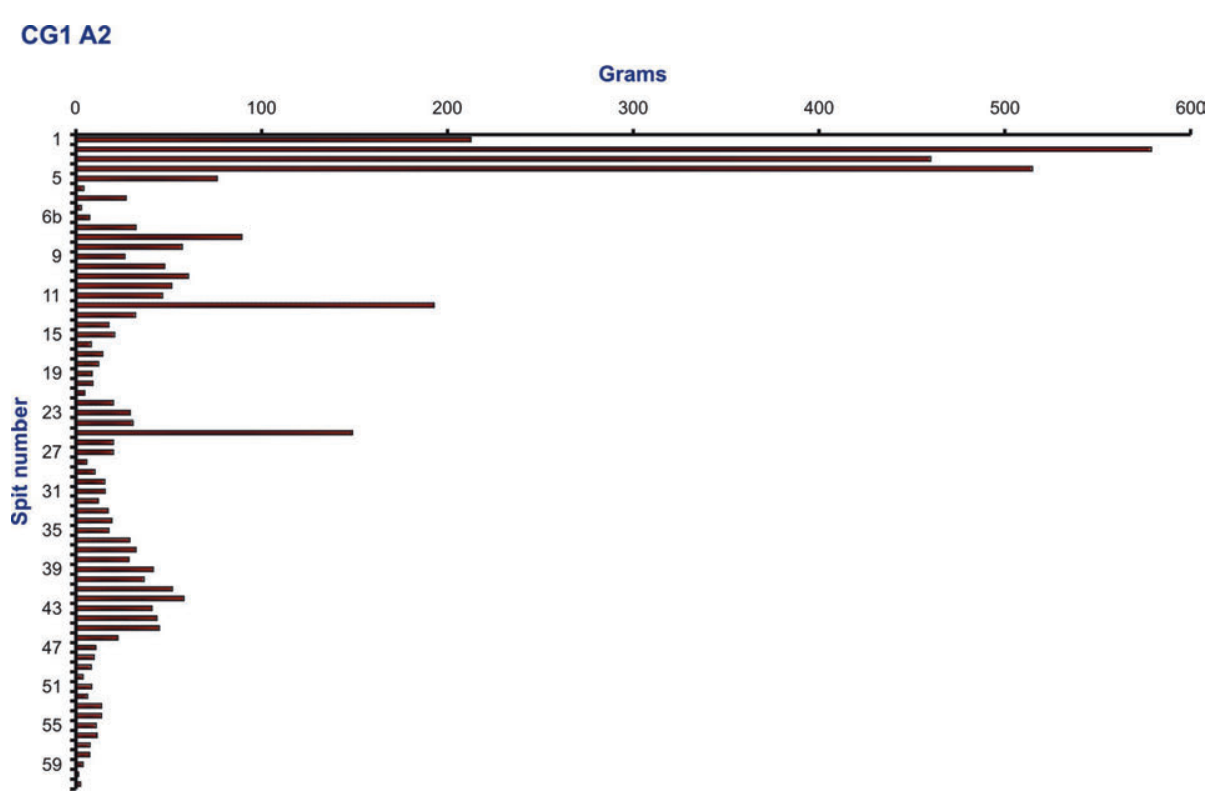

Figure 6. Charcoal weights from Square A2, Carpenter's Gap 1

\begin{tabular}{|l|c|c|c|}
\hline Spit & C14 Age BP & Delta 13C & Lab. Code \\
\hline 6 & $3900 \pm 70$ & $-26.6 \pm 0.1$ & ANU-1 1455 \\
\hline $\mathbf{5 a}$ & $\mathbf{5 2 0 4 \pm 4 5}$ & $-26.0 \pm 0.2$ & Wk 19723 \\
\hline $5 \mathrm{a}$ & $\mathbf{7 4 7 0 \pm 7 0}$ & $-26.6 \pm 0.1$ & ANU-1 1454 \\
\hline $\mathbf{7}$ & $\mathbf{7 4 6 8} \pm \mathbf{5 1}$ & $-25.5 \pm 0.2$ & Wk 19724 \\
\hline 7 & $9600 \pm 80$ & $-25.7 \pm 0.1$ & ANU-11458 \\
\hline $6 \mathrm{~b}$ & $16,000 \pm 710$ & $-24.9 \pm 0.1$ & ANU 11456 \\
\hline $6 \mathrm{c}$ & $17,130 \pm 330$ & $-24.0 \pm 2.0$ & ANU-11457 \\
\hline 9 & $17,240 \pm 130$ & $-25.2 \pm 0.1$ & ANU-11459 \\
\hline 11 & $18,240 \pm 130$ & $-25.0 \pm 0.1$ & ANU-11426 \\
\hline 13 & $18,270 \pm 160$ & $-25.0 \pm 0.1$ & ANU-11427 \\
\hline 15 & $18,430 \pm 130$ & $-24.0 \pm 2.0$ & ANU-11112 \\
\hline $\mathbf{1 7}$ & $\mathbf{2 0 , 2 9 2 \pm 1 5 0}$ & $-25.5 \pm 0.2$ & Wk 19725 \\
\hline 25 & $22,130 \pm 130$ & $24.0 \pm 0.2$ est. & ANU 11113 \\
\hline $\mathbf{2 5}$ & $\mathbf{2 3 , 3 6 6 \pm 1 5 0}$ & $-24.4 \pm 0.2$ & Wk 19726 \\
\hline 30 & $23,050 \pm 300$ & $-25.5 \pm 0.1$ & ANU-11422 \\
\hline 56 & $33,980 \pm 790$ & $-25.9 \pm 0.1$ & ANU-1 1425 \\
\hline 57 & $40,100 \pm 1220$ & $-24.0 \pm 0.0$ & ANU-Abox 340 \\
\hline
\end{tabular}

Table 1. Radiocarbon dates for various spits Square A2, Carpenter's Gap 1. Dates in bold are from Frawley (2010);

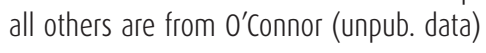


For each spit sampled, 10 charcoal fragments were collected from each of the $6 \mathrm{~mm}$ fraction and $3 \mathrm{~mm}$ fraction. The $6 \mathrm{~mm}$ and $3 \mathrm{~mm}$ fractions were sampled by spreading the charcoal on to waxed paper and selecting pieces at random. Both sieve fractions were sampled in order to ensure that species producing less robust, or more easily comminuted, charcoal would stand an equal chance of being represented in the analysis. Two-hundred archaeological charcoal samples were prepared for SEM imaging. Standard wood anatomy identification techniques were employed to determine the species of each sample (Wheeler 2000). It was possible to identify 179 of the 200 samples. Of the 179 that were identified, 136 were identified to the species level. The remainder were identified to the genus or family level.

\section{Chronological division of the archaeological wood charcoal sample}

Like Wallis and McConnell, we divided the site into different time phases for analysis:

- 42,000 BP to 30,000 BP (pre-glacial);

- $30,000 \mathrm{BP}$ to $17,000 \mathrm{BP}$, marking a phase of presumed increasing aridity, with a further subdivision of,

- 20,000 BP to 17,000 BP encompassing the height of the LGM;

- 17,000 BP to 10,000 BP, a time of fluctuation seeing a progressive amelioration; and

- $10,000 \mathrm{BP}$ to the present, encompassing the Holocene.

It should be noted, however, that Square A2 at Carpenter's Gap 1 produced no radiocarbondated stratigraphic units within the time period $16,000 \mathrm{BP}$ to $10,000 \mathrm{BP}$. Spit $6 \mathrm{~b}$, dated to $16,000 \mathrm{BP}$, was grouped for analysis in the 20,000 BP to 17,000 BP phase. Spit 6 is dated to 3900 BP. In the absence of any other dates, we have assumed that Spits 1-5 cover the late Holocene. While there might appear to be inversions in the dates from Spit 6 and Spits $6 \mathrm{~b}$ and $6 c$, these spits were not contiguous.

\section{Results of the archaeological wood charcoal analysis}

The results of the analysis of the archaeological charcoal samples are presented in Table 2 and discussed below by time period.

Table 2. Counts of identifications by time period (Table 2 continues on page 310)

\begin{tabular}{|l|r|r|r|r|}
\hline & Holocene & $\mathbf{2 0 , 0 0 0 - 1 7 , 0 0 0}$ & $\mathbf{3 0 , 0 0 0 - 2 0 , 0 0 0}$ & $\mathbf{4 2 , 0 0 0 - 3 0 , 0 0 0}$ \\
\hline Acacia holosericea & & & 1 & \\
\hline A. platycarpa & 1 & & & \\
\hline Adansonia gregorii & 1 & & & \\
\hline Brachychiton diversifolius & 1 & & & \\
\hline Calthrix exstipulata & 2 & & & \\
\hline Cochlospermum fraseri & 5 & 2 & 1 & \\
\hline Corymbia dampiere & 1 & & & \\
\hline Dodonea polyzyga & 1 & 2 & 2 & \\
\hline Eucalyptus bleeseri & 1 & 2 & & \\
\hline E. camaldulensis & & 1 & & \\
\hline E. conteriflora & 2 & 1 & 1 & \\
\hline E. dendromerenix & 4 & 4 & & \\
\hline E. ferruginea & & & \\
\hline
\end{tabular}




\begin{tabular}{|c|c|c|c|c|}
\hline & Holocene & $20,000-17,000$ & $30,000-20,000$ & $42,000-30,000$ \\
\hline E. miniata & & 1 & & \\
\hline E. polycarpa & 1 & 1 & & \\
\hline E. tectifica & & & 1 & \\
\hline E. tetradonta & 3 & 1 & 1 & \\
\hline Ficus platypoda & 1 & & & \\
\hline Grevillia heliosperma & & & & 1 \\
\hline G. pyramidalis & 9 & 2 & 1 & \\
\hline Grewia breviflora & 1 & & 2 & \\
\hline G. laevigata & 1 & & & \\
\hline G. tiliacfolia & 1 & & & \\
\hline Gyrocarpus americanus & 1 & & & \\
\hline Hakea arborescens & 9 & 19 & 2 & 4 \\
\hline Melaluca leucadendra & 1 & & & \\
\hline Lysiphyllum cunninghamii & & 1 & & \\
\hline Petalostigma pubescens & 1 & & & \\
\hline Planchonia careya & 3 & 1 & & 1 \\
\hline Pouteria seracia & & & 1 & \\
\hline Terminalia arostrata & 3 & & & \\
\hline T. canescens & 4 & 4 & 2 & \\
\hline T. platyphylla & 2 & 1 & 1 & \\
\hline T. platyptera & & & 2 & \\
\hline Vitex glabrata & 2 & & & \\
\hline Acacia spp. & & & 4 & \\
\hline Terminalia spp. & 3 & 2 & 6 & 1 \\
\hline Combretaceae family & & 1 & & \\
\hline Myrtaceae family & 3 & 4 & 3 & 1 \\
\hline Proteaceae family & 7 & 3 & 1 & 2 \\
\hline Tiliaceae family & & & 1 & \\
\hline Ulmaceae family & & & 1 & \\
\hline Unidentified & 5 & 7 & 5 & 4 \\
\hline Identified & 76 & 53 & 35 & 16 \\
\hline
\end{tabular}

\section{2,000 BP to 30,000 BP}

As noted by McConnell, there is less charcoal and macrobotanic material overall in this earliest phase of occupation than in later periods, and the number of species recovered is restricted. This constrained the sampling to 20 samples. Of the 20 samples from this earliest occupation phase, only seven were able to be identified to the species level. They are: Acacia platycarpa (Figure 7, SEM image 2), Cochlospermum fraseri (Figure 7, SEM image 3), Eucalyptus bleeseri (Figure 7, SEM image 4), E. dendromerenix (Figure 7, SEM image 7), Grevillia heliosperma (Figure 7, SEM image 5), Hakea arborescens (Figure 7, SEM image 1) and Planchonia careya (Figure 7, SEM image 6). One sample was identified as belonging to the Terminalia genus, though a species could not be assigned. One was identified as belonging to the Myrtaceae family and two as members of the Proteaceae family (Figure 7, SEM image 8). Acacia platycarpa and Grevillia heliosperma are found exclusively in this period. Both are common today in dry inland areas stretching from the Kimberley through to the Northern Territory (Brock 1988; Wheeler 1992). The other species identified in this period are also indicative of arid to semiarid environments. The relatively low species diversity in the identified samples for this period 
and the large percentage of unidentified samples (35\%) may potentially indicate that species diversity was restricted in the late Pleistocene. However, as will be discussed below, the small sample size and age of the charcoal at this level suggest that preservation factors must also be taken into consideration.

\section{$30,000 \mathrm{BP}$ to $20,000 \mathrm{BP}$}

Of the 40 samples selected for this period, 14 were identified to the species level: Acacia holosericea (Figure 8, SEM image 5), Corymbia dampiere (Figure 8, SEM image 3), Eucalyptus bleeseri, E. dendromerenix, E. ferruginea (Figure 8, SEM image 2), E. tectifica, E. tetradonta, Grevillea pyramidalis (Figure 8, SEM image 6), Grewia breviflora (Figure 8, SEM image 4), Hakea arborescens, Pouteria seracia (Figure 8, SEM image 1), Terminalia canescens, T. platyphylla and T. platyptera. Four samples were identified as belonging to the Terminalia genus, but could not be identified to species level, and six samples were identified as belonging to the Acacia genus but again could not be identified beyond this. Three were identified as belonging to the Myrtaceae family, and one each to the Proteaceae, Ulmaceae and Tiliaceae families. The species that are found exclusively in this period are Acacia holosericea, Eucalyptus tectifica, Pouteria seracia and Terminalia platyptera.

This period is most interesting for its sharp rise in the occurrence of Terminalia spp. Of the 40 samples examined in this period, $11(27.5 \%)$ are identified as Terminalia (Table 2). Grewia breviflora, Pouteria seracia and the sample simply identified as a member of the Tiliaceae family are all trees that grow in association with water courses, vine thickets and gorges (Wheeler 1992). This presents a total of 16 of the 40 samples (40\%) for this period identified as trees that are associated with moist vine-thicket habitats or creek edges. It could be argued that this indicates the continued presence of some small vine thicket, even as environmental conditions are presumed to be deteriorating.

\section{LGM 20,000 BP to 17,000 BP}

This period was the most intensively sampled, with 60 samples analysed. This was done in order to intensively sample this phase of hypothesised aridity. Despite the larger number of samples analysed, this period does not have the greatest diversity. Fifty-three samples $(88 \%)$ were able to be identified, with 15 individual species recorded: Corymbia dampiere, Eucalyptus bleeseri, E. camaldulensis, E. conteriflora (Figure 9, SEM image 8), E. dendromerenix, E. ferruginea (Figure 9, SEM image 1), E. miniata (Figure 9, SEM image 2), E. polycarpa (Figure 9, SEM image 3), E. tetradonta (Figure 9, SEM image 4), Grevillea pyramidalis (Figure 9, SEM image 5), Hakea arborescens, Lysiphyllum cunninghamii (Figure 9, SEM image 6), Planchonia careya, Terminalia canescens and T. platyphylla. Two other samples were identified as belonging to the Terminalia genus but could not be identified to species. Four were identified as belonging to the Myrtaceae family and three as members of the Proteaceae family. One sample was identified as a member of the Combretaceae family. The species that are found exclusively in this period are Eucalyptus conteriflora, E. miniata, and Lysiphyllum cunninghamii.

What is instantly apparent from Table 2 is the large amount of Hakea arborescens in this period. Nineteen (31.6\%) of the samples were identified as this species (see Table 2). Also prolific were Grevillea pyramidalis (Figure 9, SEM image 5) and other members of the Proteaceae family (representing a total of $40 \%$ of the samples for this period). There is also a sharp rise in Eucalyptus, perhaps indicating the wider presence of Eucalyptus woodlands. This is supported by the presence of Planchonia careya, also found in this environment (Wheeler 1992). There are 19 (31.6\%) samples identified as members of the Myrtaceae family. Combining this with those identified only as Myrtaceae undetermined gives a total of 23 samples, which represents $38.3 \%$ of the sampled charcoal within this period. If these two families are combined, $78.3 \%$ 
of the samples are from two families that are predominantly dry woodland species, perhaps indicating a fairly homogenous dry environment.

Surprisingly, two of the Eucalyptus samples are identified as red river gum, Eucalyptus camaldulensis (see Figure 9, SEM image 7). This tree only grows along the margins of rivers and its presence in the site suggests that, at least for periods of time during the LGM, there was water available in the gorge on the Lennard River. River red gum has other uses besides being a good fuel wood, such as for medicinal infusions and for producing wooden artefacts (Brock 1988; Petheram and Kok 1991).

\section{7,000 BP to the Holocene}

There is a chronostratigraphic hiatus in the sedimentary sequence from Square A2 at Carpenter's Gap 1 between 16,000 BP and 9600 BP. The charcoal from Spit 6b was dated to 16,000 BP and was grouped for analysis with the wood charcoal in the 17,000 BP to 20,000 BP phase.

\section{The Holocene}

The Holocene sequence in Square A2 at Carpenter's Gap 1 spans from c. 9600 BP to the late Holocene. There is an exponential rise in the quantity of charcoal recovered in this period, as opposed to all earlier periods (Table 2). While superior preservation is no doubt a factor in the overall increase in charcoal, and the commensurate larger number of identified charcoal samples here, the charcoal is also likely due to the marked increase in human use of the site at this time. Stone-artefact numbers and other indicators of human occupation which are less likely to be negatively affected by preservation also show an exponential increase in the Holocene levels (McConnell and O'Connor 1999).

This period has the greatest number of identified specimens, with 76 of the 80 samples identifiable (93.7\%), and 26 individual species recorded: Adansonia gregorii (Figure 10, SEM image 1), Brachychiton diversifolius (Figure 10, SEM image 2), Calthrix exstipulata (Figure 10, SEM image 3), Cochlospermum fraseri, Corymbia dampiere, Dodonea polyzyga (Figure 10, SEM image 4), Eucalyptus bleeseri, E. camaldulensis, E. dendromerenix, E. ferruginea, E. polycarpa, E. tetradonta, Ficus platypoda (Figure 10, SEM image 5), Grevillea pyramidalis, Grewia breviflora, G. laevigata, G. tiliacfolia (Figure 10, SEM image 6), Gyrocarpus americanus, Hakea arborescens, Melaluca leucadendra (Figure 10, SEM image 8), Petalostigma pubescens, Planchonia careya, Terminalia arostrata (Figure 10, SEM image 7), T. canescens, T. platyphylla and Vitex glabrata (see Figure 10). Of these, Adansonia gregorii, Brachychiton diversifolius, Calthrix exstipulata, Corymbia bella, Dodonea polyzyga, Ficus platypoda, Grewia tiliacfolia, G. laevigata, Melaluca leucadendra and Petalostigma pubescens are found exclusively in this period. They derive from species found in a wide range of habitats and many are common around the site today. Gyrocarpus americanus and Eucalyptus camaldulensis both grow in Windjana Gorge. Many, such as Ficus platypoda, Grewia tiliacfolia, G. laevigata, the Terminalia species and Vitex glabrata, are vine thicket/rainforest species. Melaluca leucadendra is found around swamps and creek and river courses and can also occur in wet vine thicket. Boabs (Adansonia gregorii) and Brachychiton diversifolius grow immediately outside the entrance of the shelter and on the plain below. 


\section{$42,000 \mathrm{BP}$ to $30,000 \mathrm{BP}$}


1. Hakea arborescens

2. Acacia platycarpa

3. Cochlospermum fraseri

4. Eucalyptus bleeseri
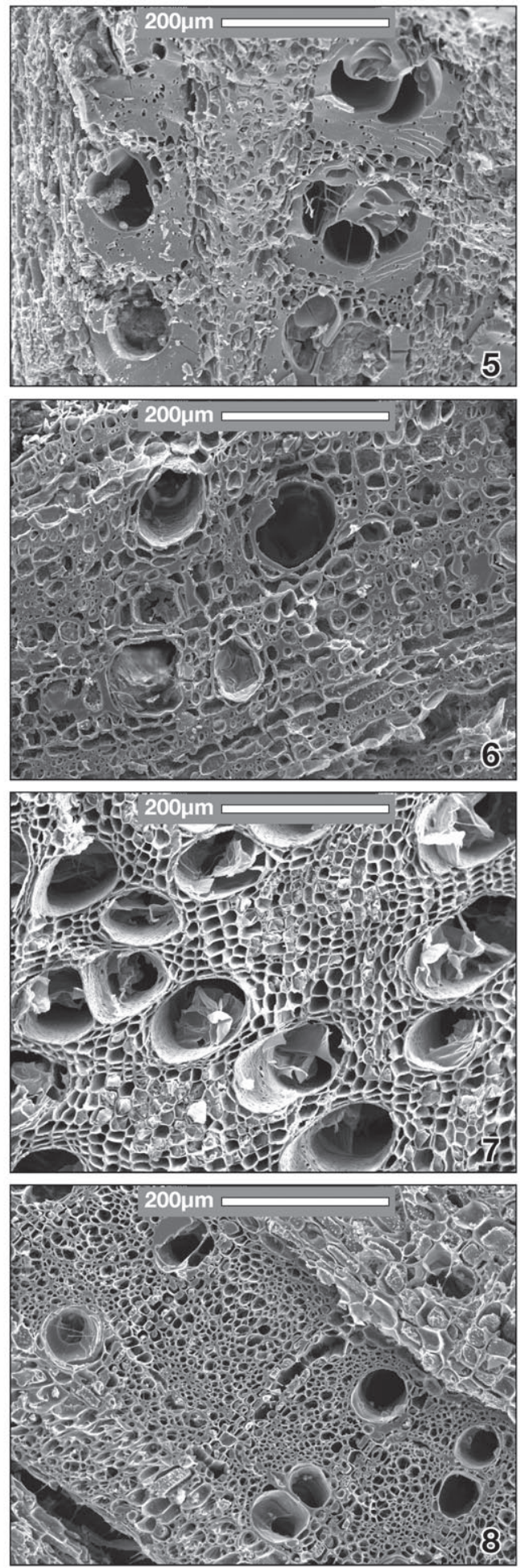

5. Grevillea heliosperma

6. Planchonia careya

7. Eucalyptus dendromerenix

8. Proteaceae undetermined

Figure 7. SEM images of wood charcoal - species recovered from the 42,000 BP to 30,000 BP levels of Carpenter's Gap 1 
314 Altered Ecologies: Fire, climate and human influence on terrestrial landscapes

\section{$30,000 \mathrm{BP}$ to $20,000 \mathrm{BP}$}
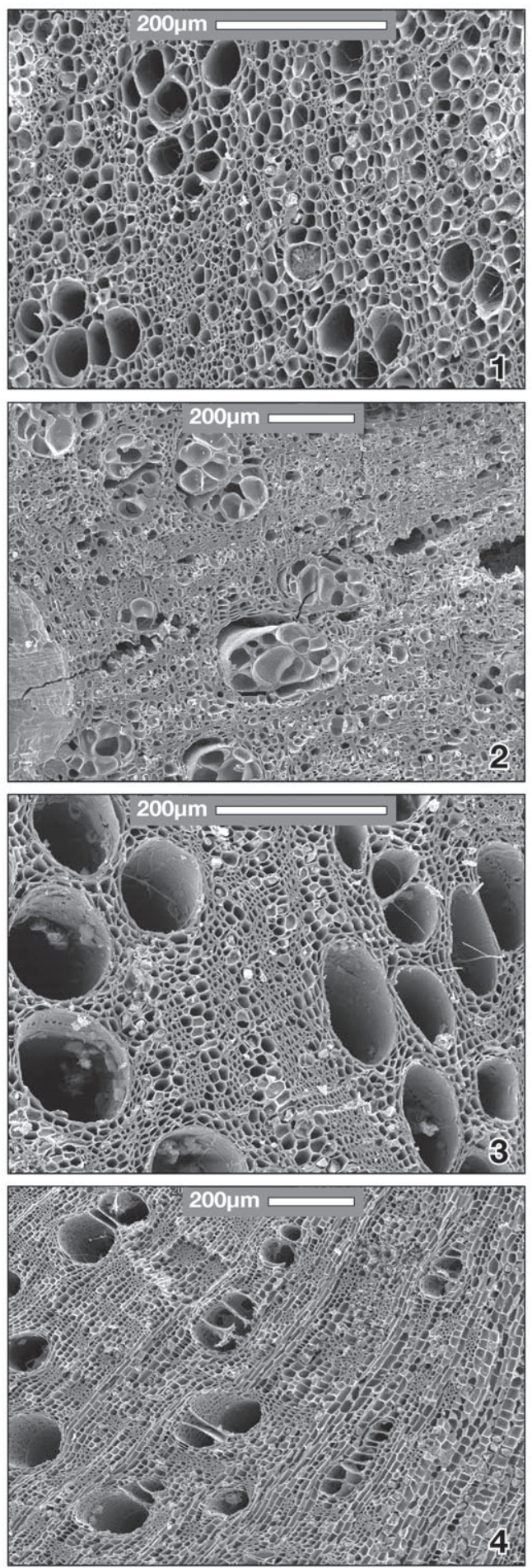

1. Pouteria seracia

2. Eucalyptus ferrunginea

3. Corymbia dampiere

4. Grewia breviflora
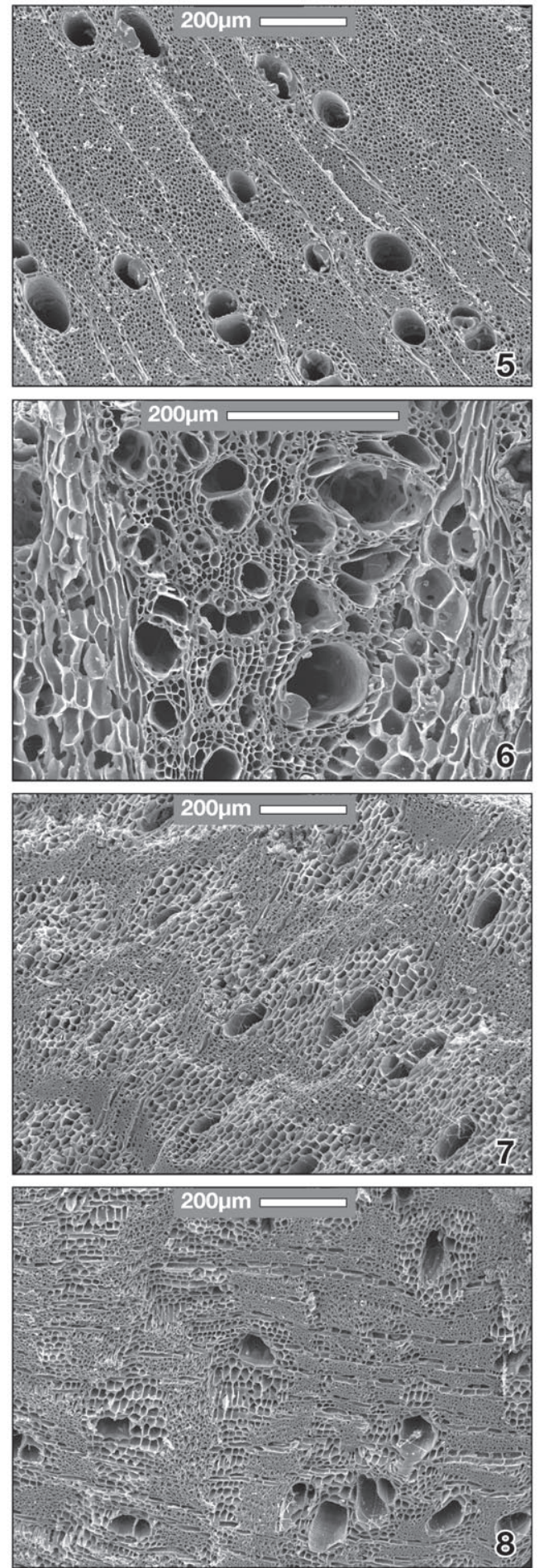

5. Acacia holosericea

6. Grevillea pyramidalis

7. Acacia species

8. Ulmaceae unidentified

Figure 8. SEM images of wood charcoal - species recovered from the 30,000 BP to 20,000 BP levels of Carpenter's Gap 1 
$20,000 \mathrm{BP}$ to $17,000 \mathrm{BP}$
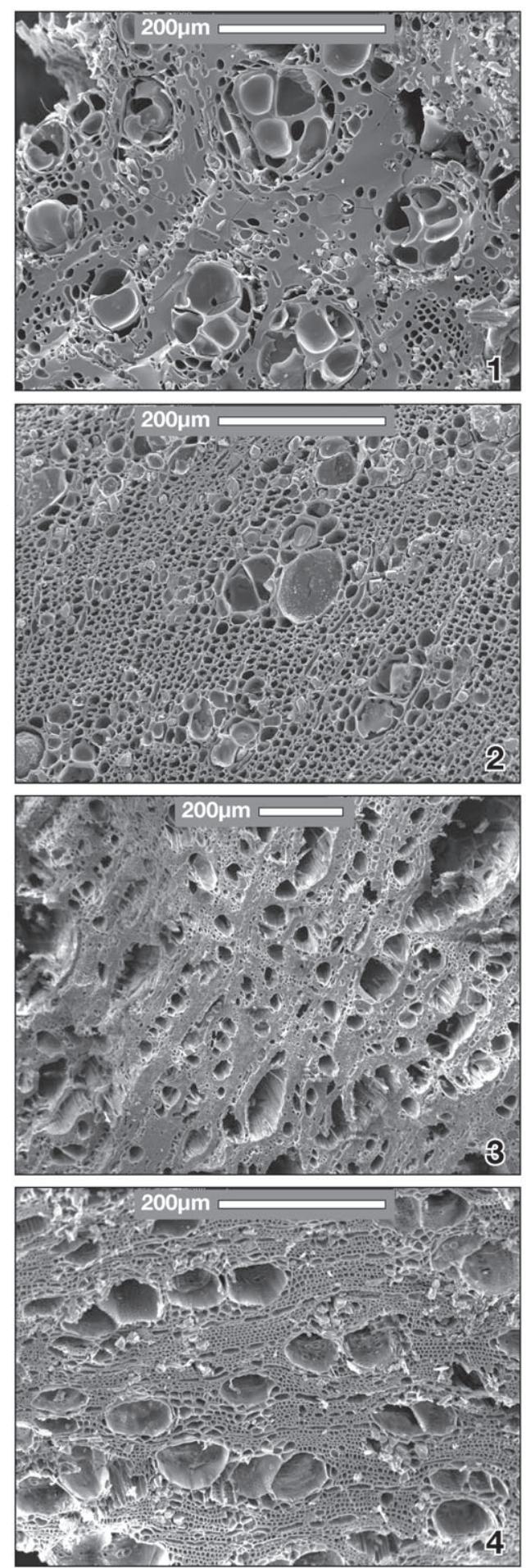

1. Eucalyptus ferruginea

2. Eucalyptus miniata

3. Eucalyptus polycarpa

4. Eucalyptus tetradonta
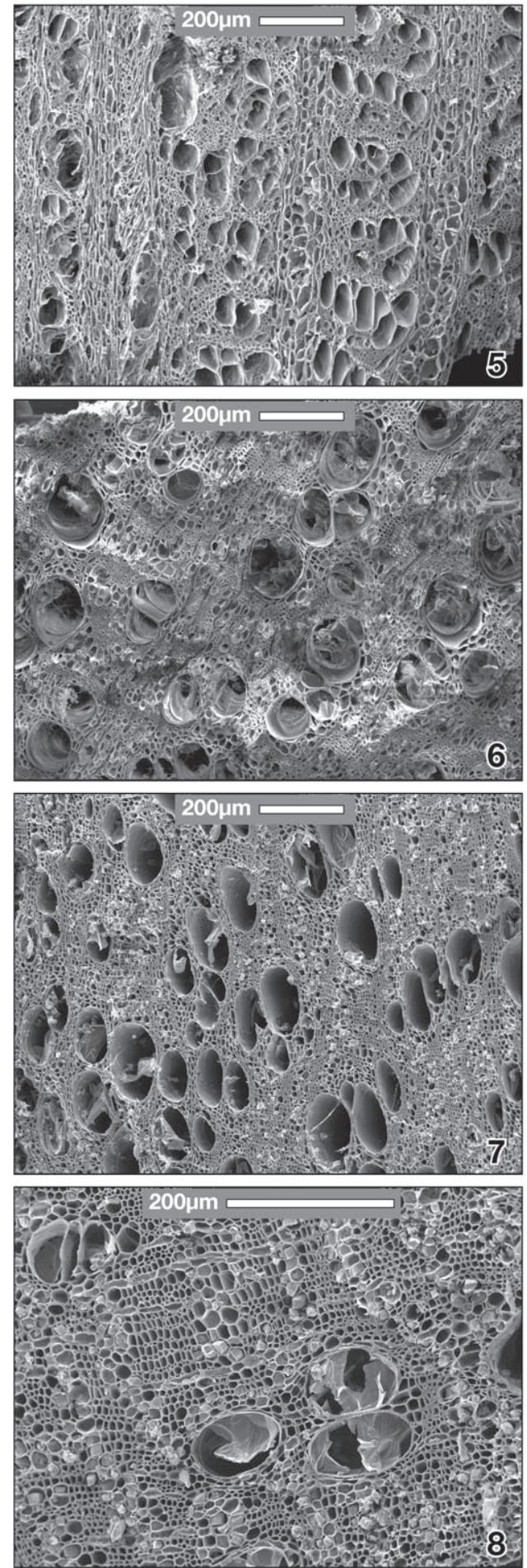

5. Grevillea pyramidalis

6. Lysiphyllum cunninghamii

7. Eucalyptus camaldulensis

8. Eucalyptus conteriflora

Figure 9. SEM images of wood charcoal - species recovered from the 20,000 BP to 17,000 BP levels of Carpenter's Gap 1 


\section{The Holocene}
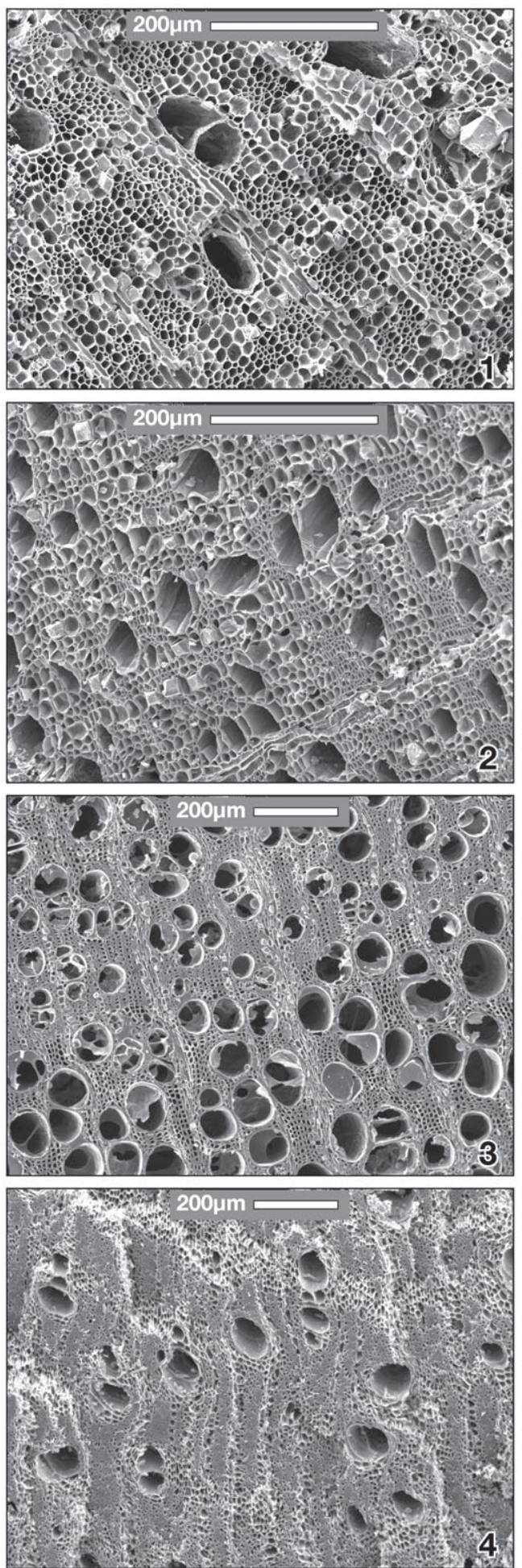

1. Andansonia gregorii

2. Brachychiton diversifolius

3. Calthrix exstipulata

4. Dodonea polyzyga
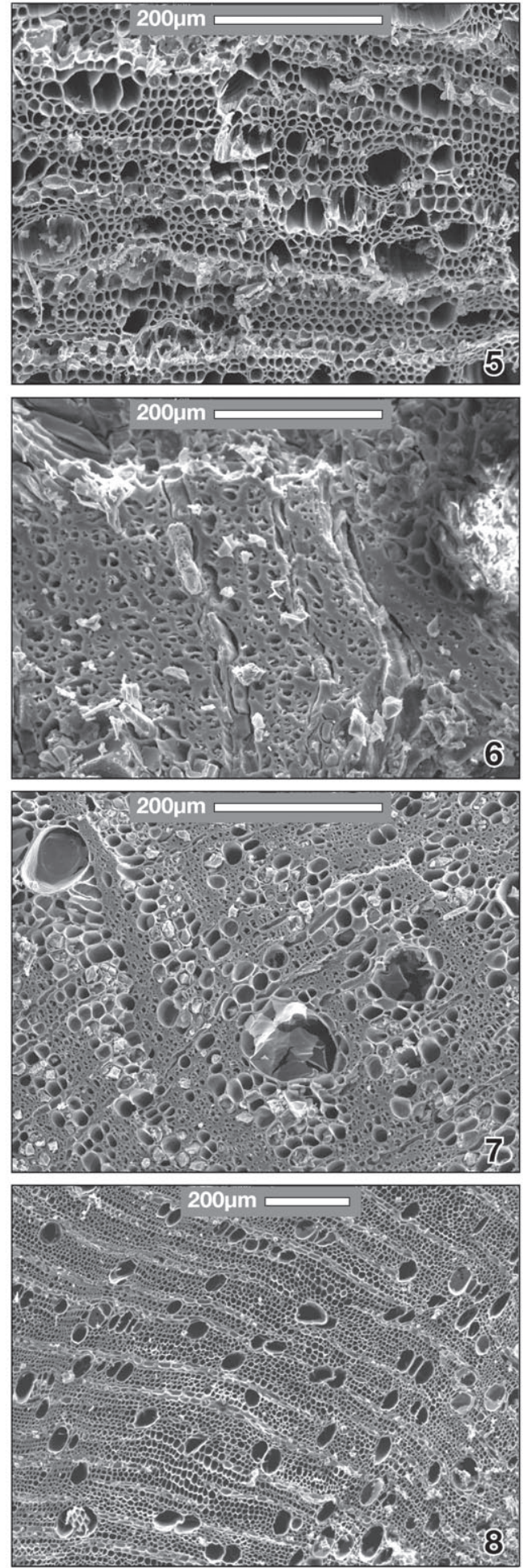

5. Ficus platypoda

6. Grewia tiliacfolia

7. Terminalia arostrata

8. Melaluca leucadendra

Figure 10. SEM images of wood charcoal - species recovered from the Holocene levels of Carpenter's Gap 1 


\section{Discussion}

\section{2,000 BP to 30,000 BP}

As in the previous macrobotanic study of McConnell and O'Connor (1997), a restricted range of species was identified in the oldest units of Carpenter's Gap 1 through the wood charcoal analysis. McConnell and O'Connor (1997) noted the small quantity of macrobotanic remains in the earliest levels of Carpenter's Gap 1 and argued that this indicated a lack of preservation with age. This would appear to be corroborated by Wallis's $(2000,2001)$ study of the phytoliths from the site, which revealed a wider range of plants in the earliest phytolith record than occurs in the macrobotanical record, presumably as a direct outcome of the breakdown of the macrobotanics in the lower spits. While poor preservation would account for the small quantity of charcoal in the lower levels (Figure 6) and mitigate against the survival of some species, the charcoals sampled by Frawley (2010) were well preserved, indicating that the wood charcoal in these lower levels may not have significantly deteriorated over time. The small sample size of macrobotanics in this period is mirrored in the more durable cultural materials, such as stone-artefact numbers, suggesting that occupation at the site in the initial stages was sporadic and of low intensity (McConnell and O'Connor 1999:26). While there will no doubt have been some loss or deterioration of more fragile wood charcoals over time, it may be that less charcoal entered the site.

McConnell and O'Connor (1997:23-26) identified predominantly grassland taxa in this earliest phase, such as Plectrachne sp., and Panicum sp. Cyperaceae sedges, as well as occasional seeds of fruit-tree species like Terminalia sp. and Ampelocissus acetosa, were also recovered from the earliest occupation levels. Wallis (2000) also identified a dominance of grasses in this early phase, as well as two distinct forms of Ulmaceae phytolith, possibly from Celtis philippensis and Trema tomentosa. Members of the Ulmaceae family are associated with vine thicket, thus demonstrating that moister gullies were in reach of the site. As noted above, the Cyperaceae must have been acquired from a waterway or wetland and their presence in the site would not be anticipated in view of the distance to the nearest permanent water on the Lennard River. Surprisingly, Wallis also identified two distinct forms of palm and these were recovered in some quantity. The closest palms today are found in refugia more than $40 \mathrm{~km}$ north of Carpenter's Gap in the King Leopold Ranges. From this, Wallis inferred slightly moister conditions than today prevailed between 42,000 BP and 30,000 BP, allowing the palms to extend their range south.

The wood charcoal study makes a valuable contribution to the palaeobotanic record at Carpenter's Gap 1 for this earliest phase of occupation, with the addition of a further seven species, as well as specimens from the Terminalia genus and Myrtaceae and Proteaceae families. There is little in the wood charcoal record, however, to support the notion of a moister climatic regime at the time of initial occupation. As noted above, with the exception of the Terminalia spp. the tree species identified for this period are indicative of arid to semi-arid environments. Overall, the wood charcoal from this phase supports an interpretation of a semi-arid treed environment, with pockets of economically important fruiting trees such as Terminalia spp. restricted to moister vine thickets and seasonal gullies.

\section{$30,000 \mathrm{BP}$ to $20,000 \mathrm{BP}$}

Although regionally specific palaeoclimatic records are not available for the inland Kimberley, the LGM generally is characterised as a time of increased aridity, decreased temperatures, greater windiness and reduced effective precipitation (Hesse 1994; Kershaw 1995; Longmore 1997; Hesse and McTainsh 1999; Hiscock and Wallis 2005). It is generally accepted that foraging and social strategies would have required significant modification as major environmental shifts 
took place and water sources dried up (Hiscock and Wallis 2005; O'Connor and Veth 2006). However, precisely when environmental deterioration set in is more difficult to determine.

The previous palaeobotanical studies at Carpenter's Gap 1 are in some ways difficult to reconcile. McConnell and O'Connor (1997:23) found that seeds of fruiting-tree species such as Terminalia spp. are found in some quantity in levels dated between c. 35,000 and 20,000 BP but virtually disappear as the area becomes increasingly arid between c. 20,000 and 16,000 BP. Also recovered in levels dated to the LGM were Chenopodiaceae and Amaranthaceae (saltbush and bluebush, including saltbush Atriplex spp.), and perennial grasses such as Panicum sp. These species are recorded at the site only for the period between about 30,000 BP and the terminal Pleistocene, during which time they dominate the record (McConnell and O'Connor 1997:29). Cyperaceae sedges also occur in both the macrobotanic and phytolith record from the earliest levels and increase in abundance in layers corresponding with greatest aridity, being found in quantity in levels dated between 30,000 BP and 17,000 BP (McConnell and O'Connor 1997:23; Wallis 2000, 2001). While the presence of wet-environment-associated species at the time of greatest aridity may seem anomalous, a likely explanation can be found in changing human mobility.

One genus that is present in these two earliest periods which does not occur in later periods, Acacia platycarpa, is found in the 42,000 BP to $30,000 \mathrm{BP}$ period, and Acacia holosericea is found in the $30,000 \mathrm{BP}$ to $20,000 \mathrm{BP}$ phase. Also present in the 30,000 BP to 20,000 BP phase are four samples that are simply identified as belonging to the Acacia genus. Acacia grows in a variety of habitats. Of interest is that Acacia is a colonising species and occurs after fire or other perturbation (Simmons 1999). Acacia platycarpa is common in dry inland areas from the Kimberley through to the northern part of the Northern Territory. Acacia holosericea is found along creek banks and on well-drained hillsides (Simmons 1987). Another tree found only in this period is Grevillea pyramidalis. The common name of this species is caustic bush as there is a substance on the fruits that is acidic and burns the skin when it comes in contact. Although this species does not make good firewood, it is possible that it entered the site as fuel. It is also recorded as used in ceremony and ritual for deliberate scarification of the skin (Petheram and Kok 1991:327). Grevillea pyramidalis is found in sparse open woodland and dry regions. Taken together, the samples from this period could be interpreted as indicating a trend towards a drying environment.

\section{The LGM 20,000 BP to 17,000 BP}

The wood charcoal record indicates that at the height of the LGM there was a predominance of dry woodland species surrounding Carpenter's Gap 1 (Table 2). The exception to this is the presence of red river gum, which could only have been obtained from the banks of a water course. This is interpreted as indicating that the site's occupants accessed the Lennard River and brought back timber for firewood and/or artefact manufacture. This adds weight to the findings from the phytolith and macrobotanic studies which identified wet-associated species such as sedges, sponge spicules and diatoms during this arid phase, and to the interpretation that there was a reorganisation of mobility and foraging strategies during this phase. Interestingly, tree species which dominate the phytolith record during the LGM, such as Acacia spp., do not appear in the wood charcoal record at all. This discrepancy is unlikely to be due to poor preservation or taphonomic factors, as Acacia spp. are found in the earlier phases. Wallis (2000) argued that her data indicated that vine thicket/rainforest pockets may have persisted in a reduced state during the height of the LGM, and the persistence of the Terminalia species in the wood charcoal record for this period would seem to support this view. 


\section{The Holocene}

The wood charcoal record from Carpenter's Gap 1 is in good agreement with the phytolith and macrobotanic records for this period. As noted above, 25 tree species were identified for this period, the largest number for any single period. Identified in the wood charcoal record are species from a wide range of habitats and most are common around the site today. All three records indicate the importance of fruiting-tree taxa, including Vitex glabrata and Terminalia spp. While Wallis (2000) detected Vitex glabrata in the phytolith record of the earliest occupation phase and McConnell and O'Connor (1997) reported occasional seeds of $V$. glabrata throughout the sequence, it is only abundant in the palaeobotanic record in the Holocene (McConnell and O'Connor 1997:23). V. glabrata is first detected in the wood charcoal record in the Holocene. This may reflect its increased abundance proximal to the site, but could in part be due to preservation, as this species is known to have very porous wood which may not survive as well as the hard seed cases. This economically important species is reported as one of the staple fruits traditionally eaten in the Kimberley during the wet season (Crawford 1982; Scarlett 1985). It was also important because it could be stored. Surplus fruit was often pounded and made into large round cakes which were wrapped in paperbark for later use (Scarlett 1985:7).

Three members of the Terminalia genus are identified in the Holocene wood charcoal record. Terminalia spp. are recorded as a very important food species in the Kimberley. Of the 12 species recorded as growing in the Kimberley, many have documented ethnographic uses (Kenneally et al. 1996:88). The fruits, which are abundant in the wet season, contain protein and carbohydrate, but most importantly, are enormously high in vitamin $\mathrm{C}$ (McConnell and O'Connor 1997:22). Also identified in the Holocene wood charcoal sample is the boab, Adansonia gregorii. McConnell and O'Connor (1997:26) reported abundant evidence of pod fragments of Adansonia gregorii in the Holocene levels and Wallis (2000) similarly detected high concentrations of boab phytoliths. The white pulp around the seeds was eaten (Crawford 1982), while in historic times the seed pods were collected to be decoratively carved for commercial sale (Akerman 1993:107). Melaluca leucadendra was also recorded in the lateHolocene macrobotanic record as fragments of paperbark (McConnell and O'Connor 1997). The soft outer bark of the paperbark was traditionally used for a variety of functions, such as wrapping the bone bundle in secondary burials, and wrapping food and delicate artefacts before placing them in carry bags. It is a very useful species and is still used today by Bunuba people for firewood and the bark sheeting for wrapping (O'Connor pers obs.).

The diversity of species in the wood charcoal record and the fact that many of them currently grow in the vicinity of the shelter suggests a vegetation suite and climate similar to those of today. Many of these species are not found in the macrobotanic record and cannot be identified to species level in the phytolith record. The wood charcoal record also identified species such as Eucalyptus, Hakea and Calthrix, which may have entered the site as fuel.

\section{Conclusion}

Considered in isolation, each of the palaeobotanic studies carried out at Carpenter's Gap 1 has produced a quite different profile of the palaeovegetation, with limited overlap. A variety of taphonomic and preservation factors bias the chances of entry and survival of different plants and plant parts in the archaeological record. For example, Wallis's (2000:151) study of the modern plant specimens demonstrated that Proteaceae and many other locally abundant taxa produced limited or no phytoliths, hence their absence from the Carpenter's Gap 1 phytolith assemblage cannot necessarily be interpreted as evidence of their absence in the landscape. Indeed, Proteaceae are present at the site in the wood charcoal record. The degree to which plants were economically important to the site's occupants will also bias their chances of 
entering the archaeological record, as well as the degree to which they accurately reflect the vegetation history of the region. Wallis (2000) demonstrated that most of the grass phytoliths were likely to have entered the sedimentary record of the site through the breakdown of macropodid scats or as wind-blown particles, and therefore are arguably a better indicator of changing environmental conditions than residues of plants that were selectively targeted by people. The wood charcoal study is most likely to have sampled tree species that were brought to the site as fuel or for other purposes, however species with porous woods will not preserve well in the wood charcoal record. Poor preservation and intense burning will mitigate against the survival of macrobotanics but may assist with the production of phytoliths. This study has demonstrated that a complete and balanced profile of the vegetation history of the site will only be produced by assessing multiple lines of palaeobotanic evidence in tandem.

In general, the results of the wood charcoal study provide support for the interpretations made by Wallis $(2000,2001)$ about the vegetation history of the locality around Carpenter's Gap, and challenge some of the earlier assertions made by McConnell and O'Connor (1997). McConnell and O'Connor (1997) interpreted the macrobotanic record as a direct reflection of the surrounding vegetation and paid little regard to the influence of human agency. Thus, they argued that the presence of sedges in the Pleistocene levels indicated moister conditions and more available surface water than the Holocene. Conversely, Wallis (2001) and Frawley (2010) interpreted the presence of the wet-associated species such as the sedges and the red river gum as signalling an increase in human mobility with increased aridity. Together, the data gathered from these three studies provide the best record available of palaeovegetation change in the Kimberley region over the human time span.

\section{References}

Akerman, K. 1993. From Boab Nuts to Ilma: Kimberley art and material culture. In J. Ryan with K. Akerman (eds), Images of Power, Aboriginal Art of the Kimberley, pp106-117. Melbourne: National Gallery of Victoria.

Beard, J.S. 1979. The Vegetation of the Kimberley Area: Explanatory Notes to Sheet 1. Perth: University of Western Australia Press.

Brock, J. 1988. Top End Native Plants. Darwin: John Brock.

Crawford, I.M. 1982. Traditional Aboriginal plant resources in the Kalumburu area; Aspects in ethno-economics. Records of the Western Australian Museum, Supplement No. 15.

Edgar, J. 2001. Beyond the Black Stump: Macroscopic Charcoal as Palaeobotanical Evidence at Carpenter's Gap 1, Northwest Australia. Unpublished BSocSc(Hons) thesis. Townsville: School of Anthropology, Archaeology and Sociology, James Cook University.

Frawley, S. 2010. Charcoal from Carpenter's Gap 1: Implications for environmental change in the last 42,000 years. Unpublished M. Phil thesis. Department of Archaeology and Natural History, College of Asia and the Pacific, The Australian National University.

Goddard, C. and A. Kalotas (eds) 1985. Punu, Yankunytjatjara Plant Use. Alice Springs: Institute for Aboriginal Development Press.

Gorecki, P., M. Grant, S. O’Connor and P. Veth 1997. The morphology, function and antiquity of Australian grinding implements. Archaeology in Oceania 32:1-10

Hesse, P.P. 1994. The record of continental dust from Australia in Tasman sea sediments. Quaternary Science Reviews 13:257-72.

Hesse, P.P. and G.H. McTainsh 1999. Last Glacial Maximum to early Holocene wind strength in the mid-latitudes of the Southern Hemisphere from Aeolian dust in the Tasman Sea. Quaternary Research 52:343-9. 
Hiscock, P. and L.A. Wallis 2005. Pleistocene settlement of deserts from an Australian perspective. In P. Veth, M. Smith and P. Hiscock (eds). Desert Peoples: Archaeological Perspectives, pp34-57. Carlton: Blackwell Publishing.

Kenneally, K.F., D. Choules Edinger and T. Willing 1996. Broome and Beyond: Plants and People of the Dampier Peninsula, Kimberley, Western Australia. Como: Department of Conservation and Land Management.

Kershaw, A.P. 1995. Environmental change in Greater Australia. Antiquity 69:656-75.

Latz, P. 1995. Bushfires and Bushtucker: Aboriginal Plant Use in Central Australia. Alice Springs: AID Press.

Longmore, M.E. 1997. Quaternary palynological records from perched lake sediments, Fraser Island, Queensland, Australia: Rainforest, forest history and climatic control. Australian Journal of Botany 45:507-26.

McConnell, K. 1997. Palaeoethnobotanical remains of Carpenter's Gap Site, the Kimberleys, Western Australia. Unpublished MA thesis. Canberra: Research School of Pacific and Asian Studies, The Australian National University.

McConnell, K. and S. O'Connor 1997. 40,000 year record of food plants in the southern Kimberley ranges, Western Australia. Australian Archaeology 45:20-31.

McConnell, K. and S. O'Connor 1999. Carpenter's Gap Shelter 1: A case study for total recovery. In M.J. Mountain and D. Bowdery (eds), Taphonomy: The Analysis of Processes from Phytoliths to Megafauna, pp23-34. Research Papers in Archaeology and Natural History 30. Canberra: ANH Publications, Research School of Pacific and Asian Studies, The Australian National University.

O'Connell, J.F., P. Latz and P. Barnett 1983. Traditional and modern plant use among the Alyawara of Central Australia. Economic Botany 37(1):80-109.

O'Connor, S. 1995. Carpenter's Gap Rockshelter 1: 40,000 years of Aboriginal occupation in the Napier Ranges, Kimberley, WA. Australian Archeology 40:58-59.

O'Connor, S. 1999. 30,000 Years of Aboriginal Occupation in the Kimberley, Northwest Australia. Terra Australis 14. Canberra: Archaeology and Natural History and Centre for Archaeological Research Publications, The Australian National University.

O'Connor, S. and P. Veth 2006. Revisiting the past: Changing interpretations of Pleistocene settlement subsistence and demography in northern Australia. In I. Lilley (ed.), Archaeology of Oceania: Australia and the Pacific Islands, pp31-47. Carlton: Blackwell Publishing.

Pearsall, D.M. 1989. Paleoethnobotany: A Handbook of Procedures. San Diego: Academic Press.

Petheram, R.J. and K.B. Kok 1991. Plants of the Kimberley Region of Western Australia. Nedlands: University of Western Australia Press.

Scarlett, N.H. 1985. A preliminary account of the Ethnobotany of the Kija people of Bungle Bungle outcamp. East Kimberley Impact Assessment Project, Working Paper no. 6. Canberra: Centre for Resource and Environmental Studies, The Australian National University.

Simmons, M. 1987. Acacias of Australia. Melbourne: Nelson Publishers.

Simmons, M. 1999. Acacia an introduction. Eucryphia, Newsletter of the Australian Plants Society (Tasmania). Available at http://asgap.org.au/APOL16/dec99-3.html.

Wallis, L.A. 2000. Phytoliths, Late Quaternary Environment and Archaeology in Tropical Semi-arid Northwest Australia. Unpublished PhD thesis. Canberra: Research School of Pacific and Asian Studies, The Australian National University.

Wallis, L.A. 2001. Environmental history of northwest Australia based on phytolith analysis at Carpenter's Gap 1. Quaternary International 83-85:103-117.

Wheeler, E. 2000. Wood Anatomy and Properties. http://legacy.ncsu.edu/WPS202/softwood/ background.htm. 2000.

Wheeler, J.R. (ed.). 1992. Flora of the Kimberley Region. Como: Department of Conservation and Land Management. 